\title{
Effect of dairy management, season and breed on protein composition of retail whole milk
}

S Stergiadis, CJ Seal, C Leifert, MD Eyre, G Butler

Newcastle University, Newcastle upon Tyne, United Kingdom

\author{
Email:socrates@nefg.net
}

Introduction Milk proteins are important in human nutrition since they provide the human body with essential amino acids, not only in high amounts but also in almost the ideal proportions for neonates. Milk proteins contribute $95 \%$ of total milk nitrogen and belong to two main categories; caseins and whey proteins. Caseins include $\alpha$-casein $(\alpha \mathrm{CN}), \beta$-casein $(\beta \mathrm{CN}), \gamma$-casein $(\gamma \mathrm{CN})$ and $\kappa$-casein $(\kappa \mathrm{CN})$ whereas whey proteins include $\alpha$-lactalbumin $(\alpha \mathrm{La}), \beta$-lactoglobulin $(\beta \mathrm{Lg})$, and its variants $\beta \mathrm{LgA}$ and $\beta \mathrm{LgB}$, bovine serum albumin (BSA) and immunoglobulins (Ig) (Givens \& Shingfield, 2004). Milk bioactive peptides are amino acid sequences within the milk proteins which are released after the digestion of either whey proteins or caseins. Peptides from casein (which include caseinophosphopetides and other miscellaneous peptides) and whey proteins show antimicrobial, antihypertensive, antithrombotic, immunomodulating, and opioid properties (Clare \& Swaisgood, 2000). Individual milk whey proteins have also been extensively associated with positive impacts in human health, demonstrating antimicrobial, antiviral, anticarcinogenic, immunomodualtory and other metabolic functions (Madureira et al. 2007). Factors like genetics, nutrition and animal health can strongly influence milk protein composition (DePeters \& Cant, 1992). This study aimed to investigate the protein composition of different brands of retail milk, as they are differentiated by bottle labelling, and examine if the differences reported in the past between breeds or between different nutritional strategies are seen at the retail level.

\begin{abstract}
Materials and methods In this survey, 28 different sources of commercial full-fat milk, characterised by brand, management system and animal breed, as identified by the bottle label were collected from retail outlets in the North East of England; 9 brands represented organic milk and 5 brands represented milk from Jersey \& Guernsey cows (JG) the remainder were conventional milks from non specified breeds (NS). Milk purchase was carried out over two years on 4 sampling dates: 2 during winter (January 2007/2008) and 2 during summer (August 2006/2007). Separation of individual proteins was performed on high performance liquid chromatography (HPLC), using a Reversed-Phase C4 analytical column $250 \times 4.6 \mathrm{~mm}, 300 \mathrm{~A}$ pore diameter and $5 \mu \mathrm{m}$ particle size. Protein contents of NS milk were compared with i) organic milk, and ii) JG milk. Analysis of variance (ANOVA) using linear mixed effects model (LME) was used to analyze results in R statistical environment using "season" (winter or summer) and "management system" (conventional or organic) or "animal breed" (JG, NS) as fixed factors and milk ID as a random factor.
\end{abstract}

Results Overall protein content of milk was not significantly influenced by either management or season although, as expected, Jersey milk was higher in total protein than NS milk (3.75 v $3.17 \mathrm{~g} / 100 \mathrm{~g}$ milk, $\mathrm{p}<0.05)$. As shown by tables 1 and 2 organic management did not significantly affect milk protein composition. A seasonal effect was significant for milk $\beta C N$ and $\kappa C N$ concentrations, which were higher in summer milk, and for bLg variants and total whey protein concentrations, which were lower in summer than in winter milk. JG milk was associated with significantly higher concentrations of protein, casein and individual caseins compared with NS milk while animal breed did not significantly affect the concentrations of whey proteins in milk.

Table 1 Differences in relative proportions (\%) of total protein and caseins in organic, summer and JG milk compared with conventional, winter and NS milk

\begin{tabular}{|c|c|c|c|c|c|c|}
\hline & Organic & P-value & Summer & P-value & JG & P-value \\
\hline$\alpha \mathrm{CN}$ & $-0.6 \%$ & ns & $-2.2 \%$ & ns & $+21.1 \%$ & $* * *$ \\
\hline$\beta \mathrm{CN}$ & $-3.1 \%$ & ns & $+9.2 \%$ & $* *$ & $+12.6 \%$ & $* *$ \\
\hline$\kappa \mathrm{CN}$ & $-0.7 \%$ & $\mathrm{~ns}$ & $+6.6 \%$ & * & $+38.9 \%$ & $* * *$ \\
\hline Caseins & $-1.7 \%$ & ns & $+4.6 \%$ & ns & $+21.8 \%$ & $* * *$ \\
\hline Protein & $-1.3 \%$ & ns & $+2.4 \%$ & ns & $+19.2 \%$ & $* * *$ \\
\hline
\end{tabular}

Table 2 Differences in relative proportions (\%) of whey proteins in organic, summer and JG milk compared with conventional, winter and NS milk

\begin{tabular}{|c|c|c|c|c|c|c|}
\hline & Organic & P-value & Summer & P-value & $\mathrm{JG}$ & P-value \\
\hline$\alpha \mathrm{La}$ & $-1.5 \%$ & ns & $+3.6 \%$ & $\dagger$ & $+5.6 \%$ & ns \\
\hline BSA & $+1.8 \%$ & ns & $+4.4 \%$ & ns & $-19.3 \%$ & $\dagger$ \\
\hline$\beta \operatorname{LgA}$ & $+3.0 \%$ & ns & $-19.0 \%$ & $* * *$ & $+6.9 \%$ & ns \\
\hline$\beta \operatorname{LgB}$ & $+0.4 \%$ & ns & $-8.1 \%$ & $* * *$ & $+5.2 \%$ & ns \\
\hline Whey & $+0.9 \%$ & ns & $-8.8 \%$ & $* * *$ & $+4.7 \%$ & ns \\
\hline
\end{tabular}

Significances were declared at $* * *: \mathrm{P}<0.001, * *: \mathrm{P}<0.01, *: \mathrm{P}<0.05, \dagger: 0.05<\mathrm{P}<0.10$, ns: $\mathrm{P}>0.10$

Conclusions The different production practices used in organic and conventional systems in the UK were insufficient to produce any differences in milk protein composition of retail whole milk. The increase in milk casein in summer milk was found at the expense of whey protein content, thus showing the same total protein content as winter milk. Similar results for the seasonal effect were taken from both datasets examined. In contrast, the strong effect of animal breed in milk protein composition at individual animal level found in other studies was confirmed in retail milk with JG milk showing higher concentrations of protein and caseins.

Ackowledgements The authors gratefully acknowledge financial support from the European Community under the 6th Framework Programme Integrated Project "QualityLowInputFood", FP6-FOOD-CT-2003-506358, the Greek State Scholarship Foundation and the Yorkshire Agricultural Society.

\section{References}

Claire, D.A. and H.E. Swaisgood. 2000. Journal of Dairy Science 83, 1187-1195

DePeters, E.J. and J.P. Cant. 1992. Journal of Dairy Science 75,2043-2070

Givens, D.I., and K.J. Shingfield. 2004. British Nutrition Foundation Nutrition Bulletin 29,325-332

Madureira, A.R., Pereira, C.I., Gomes, A.M.P., Pintado, M.E., and F.X. Malcata. 2000. Food Research International 40,1191-1211 